\title{
The Angry Customers: A Reflection on Apparel Retailers in Turkey
}

\author{
Elif A. Ergin ${ }^{1}$, Handan Özdemir ${ }^{1} \&$ Bülent Özsaçmacı ${ }^{2}$ \\ ${ }^{1}$ Department of Management, Çankaya University, Ankara, Turkey \\ ${ }^{2}$ Department of Foreign Trade, Çankaya University, Ankara, Turkey \\ Correspondence: Elif A. Ergin, Department of Management, Çankaya Üniversitesi Merkez Kampüs Yukariyurtçu \\ Mahallesi Mimar Sinan Caddesi No: 4 06790, Etimesgut, Ankara, Turkey. Tel: 90-312-233-1230. E-mail: \\ elifrutgers@yahoo.com
}

Received: March 1, 2015 Accepted: March 20, 2015 Online Published: March 28, 2015

doi:10.5539/ijms.v7n2p84 URL: http://dx.doi.org/10.5539/ijms.v7n2p84

\begin{abstract}
While anger is the dominant affective reaction following service failure, little research focused on its potentially damaging effects. Different consumers can have different emotional reactions to the same event depending on their expectations and personality situations. The present study aims to discover the circumstances where consumers reveal an anger emotion toward the apparel retail stores. The study also investigates how this anger situation impacts consumers' purchasing decisions and attitudes toward the apparel retail stores. Results revealed five major sources of anger that influence consumers in a negative manner both in terms of their attitude toward a particular retail store and their acts of purchases from the store.
\end{abstract}

Keywords: consumer anger, retail, service failures, purchasing decision, consumer behavior

\section{Introduction}

Understanding consumer behavior, tailoring marketing efforts and eventually maximizing customers' loyalty is crucial in today's competitive environment. Since new customer costs are higher than keeping existing ones (Fornell \& Wernerfelt, 1987), this reflects firms' customer retention rather than acquisition (Kalamas, Laroche, $\&$ Makdessian, 2008). A consumer behavior after an undesirable service experience is one the major situations which a firm should handle in a delicate manner. Resolving a dispute to the customer's satisfaction is the central part of keeping them as a client.

Anger occurs in service encounters, especially when things go wrong (Smith \& Bolton, 2002) and it is relatively common in business (Fitness, 2000). When consumers face with an unwanted or a complaining situation, such as waiting for service, dealing with unresponsive or impolite employees and billing errors (Bougie, Pieters, \& Zeelenberg, 2003) they may experience anger. They typically feel like behaving aggressively, saying something nasty and they tend to attack the target (Deffenbacher, Lynch, Oetting, \& Swaim, 2002; Fitness, 2000; Bougie, Pieters, \& Zeelenberg, 2003), with potentially negative consequences for both consumers and firms.

Organizational behavior and psychology researchers give considerable attention to the study of anger in the workplace in terms of employee-to-employee (Domagalski \& Steelman, 2007), and employee-to-customer (Grandey, Dickter, \& Sin, 2004), but customer anger is less well understood. This is surprising as customers play a significant role in organizations and the media directs considerable attention at negative customer emotions, especially anger (Mattila \& Enz, 2002).

Marketing researchers and practitioners are interested in better understanding consumer emotions, especially negative emotions as they are often present in customer-employee interactions and influence customer satisfaction, responses to service failure, complaining behavior, and repeat purchase (Andreassen, 2001; Dube \& Morgan, 1998; Smith \& Bolton, 2002).

Previous stream of research suggests to differentiate between negative states (Bodenhausen, Sheppard, \& Kramer, 1994b; Casado Díaz \& Más Ruíz, 2002; Raghunathan \& Pham, 1999; Weiner, 2000). Compared with others (e.g., anxiety), anger produces different thoughts and action tendencies (Izard, 1977). "Once activated, anger can color people's perceptions, form their decisions, and guide their behavior" (Lerner \& Tiedens, 2006, p. 116). There is a link between attribution and anger when the cause of the failure rests on the firm (Casado Díaz \& Más Ruíz, 2002; Dubé \& Menon, 2000; Folkes, 1984; Menon \& Dubé, 2004; Taylor, 1994). Anger is 
important in a service context. Related negative states are also worthy of consideration. Differing in intensity, they range from mild (e.g., annoyance) to moderate (e.g., anger) to strong (e.g., rage).

\section{Purpose of the Study}

This study contributes in two important ways. First, the study shows the circumstances where consumers reveal an anger emotion toward the apparel retail stores.

Second, the study explores how this anger reaction impacts consumers' attitudes toward the apparel retail stores and their acts of purchases from these stores.

\section{Methodology}

This study was conducted on 450 consumers from the 3 major shopping malls in different districts of Istanbul. Researchers, in order to reach diverse group of consumers, toured all the clothing stores in the shopping malls without any brand distinction. Convenience sampling method was used to select consumers who were included in the study. Surveys were conducted face-to-face to as consumers exited the stores.

This particular research is made up of two phases. In the first phase, a preliminary study was applied to 135 consumers in order to identify the major sources of anger. Participants were asked open-ended questions to reveal situations where they felt anger emotions during their shopping encounters in the apparel stores. Based on the findings from phase 1 , the scale for the study was developed.

The top five prominent sources of anger among consumers were identified as poor attitude of salespeople towards customers, problems related with store atmosphere, poor after-sales services, salesperson's lack of knowledge about products and lack of product variety in the store. In the second phase of the study, it was tested to see whether these five sources of anger had an effect on consumers' attitudes and purchasing behavior toward the apparel retailers.

Results revealed that these five sources of anger do indeed influence consumers in a negative manner. Consumers become dissatisfied with the retailers and their purchasing behaviors are negatively affected. Moreover, it was reported that the most influential factor that causes an anger reaction had to do with the store employees. It was also determined that a consumer's anger reaction could differentiate according to the demographic factors such as gender, age and education.

In this study, factor analysis technique was applied to identify consumers' major sources of anger. Prior to the factor analysis, construct validity analysis was done to determine the relationship among the variables and whether the sample was fit for factor analysis. Results of the construct validity analysis yielded a Kaiser-Meyer-Olkin (KMO) value of 0.884 and Bartlett's test significance value of 0.000 . Thus, it is possible to conclude that the sample of the study is fit for factor analysis. As a result, there is a strong relationship among the variables.

The scale was subjected to factor analysis by using principal component analysis, and thirty variables were grouped under five major factors with the use of varimax rotation. The remaining factors under three statements were excluded from the evaluation.

The analysis gave a five-factor solution which was identified as the top five prominent sources of anger among consumers. As mentioned above, these factors are: F1: Attitudes of salespeople toward customers, F2: Problems related with store atmosphere F3: Poor after-sales services, F4: Salesperson's lack of product knowledge, F5: Lack of product variety in the store. These factor values and related statements are presented in Table 2.

\section{Findings and Discussion}

This article investigated the specific experience of anger among consumers. The goal was to fully understand the circumstances where consumers reveal an anger emotion toward the apparel retail stores and how this anger affected consumers' purchases from these stores.

Table 1 below illustrates the demographic profiles of the respondents. A quarter of the subjects were at the ages of 50 and over $(25.8 \%)$.

In addition, $43.8 \%$ of them were listed as young to middle aged consumers, between the ages of 26 to 41 . There were 240 female and 210 males consumers in the research so the sample was almost evenly dispersed between females (53.3\%) and males (46.7\%). Over $68 \%$ of the subjects had a graduate and/or an undergraduate degree whereas the rest of them had either a high school or an elementary school degree. 
Table 1. Subjects' allocation according to the demographic factors

\begin{tabular}{lll}
\hline Age Groups & Frequency & $\%$ \\
\hline $18-25$ & 46 & 10.2 \\
$26-33$ & 90 & 20.0 \\
$34-41$ & 107 & 23.8 \\
$42-49$ & 91 & 20.2 \\
50 and over & 116 & 25.8 \\
\hline Gender & & \\
\hline Female & 240 & 53.3 \\
Male & 210 & 46.7 \\
Total & 450 & 100.0 \\
\hline Education Level & & \\
\hline Elementary Degree & 22 & 4.9 \\
High School Degree & 119 & 26.4 \\
Undergraduate Degree & 199 & 44.2 \\
Graduate Degree & 110 & 24.4 \\
\hline
\end{tabular}

\subsection{Factor 1-Attitudes of Salespeople toward Customers}

The primary factor that has been identified is "attitudes of salespeople toward customers". This factor accounts for $24.437 \%$ of the total variance and consists of eight statements. An assessment of factor loadings reveals that the major factor that annoys consumers the most is "being followed by the salesperson around the store." Consumers reported that they get irritated and aggravated when they are constantly chased in the store by the sales people. They stated that being pursued in the store make them feel stressed out and suspicious. For this reason, consumers choose not to engage in acts of shopping from those same retailers again.

Table 2. Factor loadings and total variance levels

\begin{tabular}{|c|c|c|}
\hline Factors & $\begin{array}{l}\text { Factor } \\
\text { Loads }\end{array}$ & $\begin{array}{ll}\% & \text { of } \\
\text { Variance } & \\
\end{array}$ \\
\hline Factor 1: Attitudes of Salespeople toward Customers & & 24.437 \\
\hline - I get angry when the salesperson follows me around in the store. & .859 & \\
\hline - I get angry when the salesperson is not honest with me. & .832 & \\
\hline - I get angry when the salesperson takes care of another customer while he is helping me. & .832 & \\
\hline - I get angry when the salesperson is grim. & .830 & \\
\hline - I get angry when the salesperson immediately folds/adjusts the product I leave behind. & .791 & \\
\hline - I get angry when the salesperson is rude towards me. & .768 & \\
\hline I get angry when the salesperson is not interested with me. & .715 & \\
\hline - I get angry when the salesperson has a cocky attitude. & .704 & \\
\hline Factor 2: Problems Related with Store Atmosphere & & 9.455 \\
\hline - I get angry when there is a lack of air conditioning in the store. & .704 & \\
\hline I get angry when the stalls in the store are very small. & .637 & \\
\hline I get angry when there is loud music in the store. & .636 & \\
\hline - I get angry when there is no rest area in the store. & .497 & \\
\hline Factor 3: Poor After-Sales Services & & 8.588 \\
\hline - I get angry when the store claims no responsibility for faulty products. & .740 & \\
\hline I get angry when the product return process takes too long. & .729 & \\
\hline - I get angry when there are problems with the product return process. & .616 & \\
\hline Factor 4: Salesperson's Lack of Product Knowledge & & 8.338 \\
\hline - I get angry when the salesperson does not have sufficient product information. & .749 & \\
\hline $\begin{array}{l}\text { I get angry when the salesperson tells me the product is not available without checking the } \\
\text { supply. }\end{array}$ & .667 & \\
\hline $\begin{array}{l}\text { I get angry when the salesperson does not guide me with alternatives for unavailable product } \\
\text { size/color. }\end{array}$ & .638 & \\
\hline Factor 5: Lack of Product Variety in the Store & & 7.295 \\
\hline - I get angry when there is only one product available at the store for each size. & .733 & \\
\hline - I get angry when there is only one product available at the store for each color. & .677 & \\
\hline I get angry when product inventory at the store is not maintained regularly. & .607 & \\
\hline
\end{tabular}




\subsection{Factor 2-Problems Related with Store Atmosphere}

The second extracted factor that is able to explain $9.455 \%$ of the total variation is "problems related with store atmosphere". There are four variables in the composition of this particular factor. Consumers complain about of the size of the stalls, loud music, and lack of air conditioning and absence of a rest area within the store. Such issues have a dramatic impact on a consumer's level satisfaction while shopping at a particular store. Participants stated they get angry when the music is played too loud, when the small stalls make it very difficult to try clothes on and there is no place sit and get some rest during a shopping visit.

\subsection{Factor 3-Poor After-Sales Services}

Another factor which reflects the consumer's anger reaction is the "poor after-sales services" in the stores. This factor accounts for $8.588 \%$ of the total variance and there are three statements related to it. At this point, the most irritating issue for the customers occurs when the store claims no responsibility for faulty products. Such attitude from the retail store decreases the consumer's likelihood to build brand trust and loyalty.

\subsection{Factor 4-Salesperson's Lack of Product Knowledge}

"Salesperson's lack of knowledge" in a store is discovered as the fourth factor and explains $8.338 \%$ of the total variance. There are three statements related to this factor. Customers always demand qualified and knowledgeable sales people who are well informed about the nature, function and range of products and services that are already available in a store. The statements loading on this factor reveal that if the salesperson does not have sufficient product information then the consumer's anger reaction represents itself prominently by the means of negative attitude towards the store and the purchasing decision.

\subsection{Factor 5-Lack of Product Variety in the Store}

The factor with the lowest impact among the sources of anger is the "lack of product variety" in a given store. Three statements are associated with this factor and based on the factor analysis, it accounts for $7.295 \%$ of the total variance. When consumers are unable to find the products that they are looking for, when they face challenges to attain on a particular product's size or color, they may get frustrated. That is why the retail stores must have a wide assortment of products on-hand and their product inventory systems must be updated regularly.

\section{Hypotheses Testing}

Five hypotheses have been developed for this study in order to determine whether sources of anger differentiated according to the demographic factors. A second goal was to examine the results of factor analysis obtained from the sources of anger against the attitude and purchasing behaviors of consumers towards the apparel retail stores.

According to the multi-regression analysis which was conducted on $\mathrm{H}_{1}$, it was indicated that there is a strong and positive relationship between the variables $(R=0.742)$ and determination coefficient value was $\left(R^{2}\right)$ calculated as 0.55 . It was concluded that five anger source factors were able to explain $55 \%$ of the changes in consumer attitudes towards the retail store.

Table 3. Hypotheses overview

\begin{tabular}{ll}
\hline Hypotheses & Results \\
\hline $\mathbf{H}_{\mathbf{1}}$ : Sources of anger has a negative effect on consumers' attitude toward the retail store & Supported \\
$\mathbf{H}_{2}$ : Sources of anger has a negative effect on consumers' purchasing behavior toward the retail store & Supported \\
$\mathbf{H}_{3}$ : There is a significant difference between consumer's anger reaction and gender & Supported \\
$\mathbf{H}_{4}:$ There is a significant difference between consumer's anger reaction and age groups & Supported \\
$\mathbf{H}_{5}:$ There is a significant difference between consumer's anger reaction and level of education & Supported \\
\hline
\end{tabular}

According to standardized beta coefficients, the five independent variables can be listed with respect to the degree of importance levels. These levels are; attitudes of salespeople toward customers $(\beta=0.458)$; problems related with store atmosphere $(\beta=0.160)$; poor after-sales services $(\beta=0.131)$; salesperson's lack of knowledge $(\beta=0.110)$; and lack of product variety in the store $(\beta=0.013)$. In the second hypothesis, the impact of sources of anger on consumers' purchasing behavior toward the retail store was investigated and as a result $\mathrm{H}_{2}$ is accepted $($ sign. $=0.000)$. The analysis signified that these five factors' has a negative effect on consumers about purchasing from the same retail store repeatedly $\left(R=0.72, R^{2}=0.521\right.$, sign. $\left.=0,000\right)$. As a result of the analysis of two hypotheses, mentioned five factors, have a negative impact on both consumers' buying behaviors and as well as the existing attitude toward the retail store. 
The other three hypotheses that are tested in this research aid to differentiate and measure the consumer's anger reactions according to demographic factors like age, gender and education level. $\mathrm{H}_{3}$ hypotheses investigated the significant difference between consumer's anger reaction and gender factor. To evaluate this hypothesis, t-test analysis was carried out and as a result the hypothesis is accepted (sign. $=0.002)$. Referring to mean values, female consumers $(\bar{X}=3.94)$ are said to be frustrated than male consumers $(\bar{X}=3.52)$.

$\mathrm{H}_{4}$ hypotheses investigated the significant difference between consumer's anger reaction and age groups. ANOVA analysis was conducted on the hypothesis and as a result no significant difference was found between the tested groups $($ sign. $=0.002$ ). So the hypothesis is accepted. Referring to mean values, the consumers between ages $18-24$ are the most hyped ( $\bar{X}=4.15$ ) however, it is revealed that the age group 50 and older are more calm $(\bar{X}=3.24)$.

The final hypothesis of the study, $\mathrm{H}_{5}$ tested for the significant difference between consumer's anger reaction and education level. ANOVA analysis was conducted on the hypothesis and as a result the hypothesis is accepted (sign. $=0.019)$. Referring to mean values, the consumers with the elementary education level are the most hyped $(\bar{X}=4.43)$ however, it is revealed that the consumers with the undergraduate education level are more calm $(\bar{X}=2.60)$.

\section{Limitations and Future Research}

Our research has several important limitations and these may stimulate further research. The result of this research shows that anger is a significant predictor of a consumers' reaction toward a particular retail store and subsequent purchasing behavior. However, the participants in the sample were selected from an urban population. It would be interesting to carry out a similar study with consumers from other parts of the country, especially from rural areas. An additional avenue for future research could also be a comparative study of major factors that evolve consumer anger into consumer rage.

\section{References}

Andreassen, T. W. (2001). From disgust to delight: Do customers hold a grudge? Journal of Service Research, 4(1), 39-49. http://dx.doi.org/10.1177/109467050141004

Bodenhausen, G. V., Sheppard, L. A., \& Kramer, G. P. (1994). Negative affect and social judgment: the differential impact of anger and sadness. European Journal of Social Psychology, 24(1), 45-62. http://dx.doi.org/10.1002/ejsp.2420240104

Bodenhausen, G., V., Kramer, G. P., \& Süsser, K. (1994). Happiness and stereotypic thinking in social judgment. Journal of Personality and Social Psychology, 66(4), 621-632. http://dx.doi.org/10.1037/0022-3514.66.4.621

Bougie, R., Pieters, R., \& Zeelenberg, M. (2003). Angry customers don't come back, they get back: the experience and behavioral implications of anger and dissatisfaction in services. Journal of the Academy of Marketing Science, 31(4), 377-393. http://dx.doi.org/10.1177/0092070303254412

Casado Díaz, A. B., \& Más Ruíz, F. J. (2002). The consumer's reaction to delays in service. International Journal of Service Industry Management, 13(2), 118-140. http://dx.doi.org/10.1108/09564230210425331

Deffenbacher, J. L., Lynch, R. S., Oetting, E. R., \& Swaim, R. C. (2002). The Driving Anger Expression Inventory: A measure of how people express their anger on the road. Behaviour Research and Therapy, 40, 717-737. http://dx.doi.org/10.1016/S0005-7967(01)00063-8

Domagalski, T. A., \& Steelman, L. A. (2007). The impact of gender and organizational status on workplace anger expression. Management Communication Quarterly, 20(3), 297-315. http://dx.doi.org/10.1177/0893318906295681

Dubé, L., \& Menon, K. (2000). Multiple roles of consumption emotions in post-purchase satisfaction with extended service transactions. International Journal of Service Industry Management, 11(3), 287-304. http://dx.doi.org/10.1108/09564230010340788

Dubé, L., \& Morgan, M. S. (1998). Capturing the dynamics of in-process consumption emotions and satisfaction in extended service transactions. International Journal of Research in Marketing, 15(4), 309-320. http://dx.doi.org/10.1016/S0167-8116(98)00009-3

Fitness, J. (2000). Anger in the workplace: an emotion script approach to anger episodes between workers and their superiors, co-workers and subordinates. Journal of Organizational Behavior, 21, 147-162. http://dx.doi.org/10.1002/(SICI)1099-1379(200005)21:3<315::AID-JOB23>3.0.CO;2-1 
Folkes, V. S. (1984). Consumer reaction to product failure: an attributional approach. Journal of Consumer Research, 10(4), 398-409. http://dx.doi.org/10.1086/208978

Fornell, C., \& Wernerfelt, B. (1987). Defensive marketing strategy by consumer complaint management: a theoretical analysis. Journal of Marketing Research, 24(4), 337-346. http://dx.doi.org/10.2307/3151381

Grandey, A. A., Dickter, D. N., \& Sin, H. P. (2004). The customer is not always right: customer aggression and emotion regulation of service employees. Journal of Organizational. Behavior, 25(3), 397-418. http://dx.doi.org/10.1002/job.252

Izard, C. E. (1977). Human Emotions. New York: Plenum.

Kalamas, M., Laroche, M., \& Makdessian, L. (2008). Reaching the boiling point: Consumers' negative affective reactions to firm-attributed service failures. Journal of Business Research, 61, 813-824. http://dx.doi.org/10.1016/j.jbusres.2007.09.008

Lerner, J. S., \& Tiedens, L. Z. (2006). Portrait of the angry decision maker: how appraisal tendencies shape anger's influence on cognition. Journal of Behavioral Decision Making, 19(2), 115-137. http://dx.doi.org/10.1002/bdm.515

Mattila, A. S., \& Enz, C. A. (2002). The role of emotions in service encounters. Journal of Service Research, 4(4), 268-277. http://dx.doi.org/10.1177/1094670502004004004

Menon, K., \& Dubé, L. (2004). Service provider responses to anxious and angry customers: different challenges, different payoffs. Journal of Retailing, 80(3), 29-237. http://dx.doi.org/10.1016/j.jretai.2003.11.002

Raghunathan, R., \& Pham, M. T. (1999). All negative moods are not equal: motivational influences of anxiety and sadness on decision making. Organizational Behavior and Human Decision Processes, 79(1), 56-77. http://dx.doi.org/10.1006/obhd.1999.2838

Smith, A. K., \& Bolton, R. N. (2002). The effect of customers' emotional responses to service failures on their recovery effort evaluations and satisfaction judgments. Journal of Academy of Marketing Science, 30(1), 5-23. http://dx.doi.org/10.1177/03079450094298

Taylor, S. (1994). Waiting for Service: the relationship between delays and evaluations. Journal of Marketing, 58(2), 56-68. http://www.jstor.org/stable/1252269

Weiner, B. (2000). Attributional thoughts about consumer behavior. Journal of Consumer Research, 27(3), 382-387. http://dx.doi.org/10.1086/317592

\section{Copyrights}

Copyright for this article is retained by the author(s), with first publication rights granted to the journal.

This is an open-access article distributed under the terms and conditions of the Creative Commons Attribution license (http://creativecommons.org/licenses/by/3.0/). 